\title{
Tribalism and Egalitarianism
}

\author{
Daniel Callahan
}

Published online: 24 September 2011

(C) Springer Science+Business Media, LLC 2011

My ordinary beat these days is health care reform, and as I write this at the end of July 2011, the game is tied, neither team is near a goal line, trash talk between the players is vitriolic, neither team has a good offense and each has a spotty defense, and both teams have been warned by safety inspectors Ben Bernanke and Timothy Geithner that the stadium roof will collapse on everybody, players and spectators alike, if they do not break the tie.

The old Adam and the Last Man are thus at it again, and this time in a way that will affect all of us. On one side are the tribal groups, with minority Tea Party members playing the spoiler role for the larger Republican tribe and worried not a bit by their unashamed inegalitarianism. The idea that the rich should have their taxes raised to reduce the deficit is a virus from hell, one more nasty big government pathological outburst.

The rich, the Tea Party tells us, are the victorious warriors, worth all the honor that accumulators of wealth in a capitalist society deserve. And as so often happens in history, the losers in the competitive market are the loudest supporters of the winners. The saintly Dorothy Day, living in poverty at a house of hospitality in the lower east side of Manhattan and working to help the poor, once told a wonderful story about that phenomenon. It was not easy, she said to convince the poor she was there to help them, and former Communists did not get a good press. But her day was finally made when emissaries of the local Mafia showed up in long black limousines to give her money.

D. Callahan $(\bowtie)$

The Hastings Center,

21 Malcolm Gordon Road,

Garrison, NY 10524, USA

e-mail: callahand@thehastingscenter.org
Nothing, she said, more impressed her poor clients than the fact that she had gained that kind of prestigious support.

The egalitarian Democrats meanwhile, once a coherent tribe, are now more like a fractious mob, loathing the Republicans and despising the Tea Party, but divided among themselves and disillusioned with their chief, Barack Obama. They are now in a "constant struggle to stay egalitarian" (Boehm) in a society that only waveringly supports it any longer, even in their own party. They are also the heirs of two wars, not their doing at the outset but now theirs to wind down, if they can. They started out as popular wars, and Robin Fox has called attention to all those flags and national fervor that was in its way a great national gift, creating community once again, in the aftermath of $9 / 11$. Was that a kind of "rational liberalism," asking all to do their share in combating terrorism? If so, it turned out not to be too demanding in the name of community, not much more than intensified airport body searches and repeated admonitions to report suspicious looking packages and unattended luggage.

The health reform debate, and the economic recession that has paralleled it, has underscored and intensified the perennial struggle between tribalism and egalitarianism, and reflected in regional differences as well. While it may seem odd to think of the Jeffersonian and Jacksonian ideologies of opposition to government and praise of the self-made individual as tribal in nature, the Tea Party and its congressional representatives have shown a coherence and discipline that the ostensibly more communitarian Democrats can well envy.

But as Robin Fox reminds us it is hard to sustain egalitarian communities. Democrat leaders try to invoke community as a key value behind universal health care, with fairness to all. But even among Democrats there turned out to be little taste for giving up long-standing 
entitlements, to raising middle-class taxes (even as it became known that an implausible $90 \%$ tax rate for the rich would not be sufficient to take care of the deficit/debt problem), and to resist the use of the word rationing, or even hints of a slippery slope in that direction.

When I look at the ideological clashes that have marked the health care and deficit debates I see little evidence of an underlying civil religion. The various symbols of that noted by Fox-"that totemic flag" and the singing of the national anthem at sporting events - is more than matched by using just those symbols as weapons with which to attack each other. Whether in charges of un-Americanism against egalitarians, or claims of a right to openly carry a gun at public meetings (conspicuously next to the flag and while singing the national anthem), tribalism of a kind has come into good times. It is not as bad as the tribalism that is now wrecking many countries, but we are catching up.

As for the ideal of a "Family of Man," I can hardly find it even in my neighborhood during the annual ritual of fights over rising school taxes. The Ayn Rand tribe is alive and well, and if taxes are raised that is as good evidence as any that we are - aren't we - on the way to serfdom, just as Friedrich von Hayek predicted?

Daniel Callahan is Senior Research Scholar and President Emeritus of the Hastings Center. 